JOURNAL OF SECURITY AND SUSTAINABILITY ISSUES

ISSN 2029-7017 print/ISSN 2029-7025 online

2021 Volume 11

https://doi.org/10.47459/jssi.2021.11.17

\title{
PREVENTIVE USE OF DIRECT COERCIVE MEASURES AS ESSENTIAL TOOLS FOR THE IMPLEMENTATION OF STATUTORY PROTECTIVE ACTIVITIES IN THE POLISH PRISON SERVICE
}

\author{
Robert Nowacki \\ Academy of Justice, 50 Wiśniowa Street, 02-520 Warsaw, Poland \\ E-mail: robert.nowacki@swws.edu.pl
}

Received 15 November 2020; accepted 5 April 2021; published 30 June 2021

\begin{abstract}
This article presents the rights of Prison Service officers regarding the preventive use of direct coercive measures. The concepts of the use and application of direct coercive measures were defined in relation to the Prison Service. The purposes of preventive use are presented with examples. The catalogue and basic principles of the use of direct coercive measures, which can be applied as preventive measures in the Polish Prison Service, are described. The above issues were adapted to the statutory protective tasks of this formation.
\end{abstract}

Keywords: Prison Service; prevention; security; direct coercive measures; officer.

Reference to this paper should be made as follows: Nowacki, R. 2021. Preventive use of direct coercive measures as essential tools for the implementation of statutory protective activities in the polish prison service. Journal of Security and Sustainability Issues, 11, 205-214, https://doi.org/10.47459/jssi.2021.11.17

JEL Classifications: Z00

Additional disciplines: penitentiary science, security science, prison service

\section{Introduction to the issue of direct coercive measures in the Prison Service}

Direct coercive measures belong to the most severe law enforcement tools used to ensure the safety of individuals as well as to protect their rights and freedoms. ${ }^{1}$

In the general definition, measures of direct coercion constitute the properties of the human body (physical strength), objects or animals (as living creatures), by means of which an authorised public official exerts pressure on a person (causes physical and mental ailment) in order to achieve lawful behaviour or overpower dangerous animals. ${ }^{2}$ In the case of the Prison Service, it will also be a place, rooms (e.g. a security cell).

\footnotetext{
1 Kubanek A. (2019), Ograniczenia praw jednostki przez zastosowanie środków przymusu bezpośredniego w celu zapewnienia bezpieczeństwa i porządku publicznego [Limitation of the rights of an individual by the use of direct coercion measures to ensure security and public order], Wydawnictwo Uniwersytetu Kazimierza Wielkiego [Publishing House of the Kazimierz Wielki University], Bydgoszcz, p. 8 .

2 Dyduch L., Maciejczyk R. (2012), Wybrane formy organizacyjne działań podmiotów uprawnionych w zakresie bezpieczeństwa wewnętrznego państwa, Część I, Środki przymusu bezpośredniego i broń palna, [Selected organisational forms of actions of authorised entities within the scope of internal security of the state, Part 1, Direct coercion measures and firearms], Helena Chodkowska University of Technology and Economics, Warsaw, Warsaw 2, p. 10.
} 
The essence of direct coercive measures indicates behaviour, which aims to force individuals to exhibit specific behaviour. Preventing threats to the broadly understood security, restoring disturbed public order or influencing by forcing to comply are the key and most important objectives of using direct coercive measures. ${ }^{3}$

Measures of direct coercion may be used or applied only in the circumstances specified in the law and can only be implemented by a selected group of entities, e.g. officers of the Prison Service.

The Prison Service is a uniformed and armed apolitical formation subordinate to the Minister of Justice. It has its own organisational structure. ${ }^{4}$ In Art. 2, Paragraph 1 of the Act on the Prison Service, the principal subject of activity of this formation is specified, by referring in its content directly to the tasks related to the execution of pre-trial detention, imprisonment and coercive measures resulting in deprivation of liberty, in the Act of 6 June 1997, Penal Enforcement Code. ${ }^{5}$ Moreover, Paragraph 2 lists the basic tasks of the formation, which include, inter alia, ensuring order and security in prisons and detention centres as well as protection of the public against perpetrators of crimes or fiscal offences incarcerated in prisons and detention centres. ${ }^{6}$

The competences of the Prison Service in this respect result from Art. 19 of the Act on the Prison Service of 9 April 2010, in connection with the Act of 24 May 2013 on measures of direct coercion and firearms. ${ }^{7}$ They include types, cases and rules for the use and application of measures of direct coercion, as well as procedures to be followed before and after their use or application, including the rules for documenting.

It should be mentioned that the above act ${ }^{8}$ regulates the rules concerning the use of direct coercive measures also by other services and entities ${ }^{9}$ responsible for the broadly understood internal security in Poland. On the other hand, the competences regarding the types of direct coercive measures as well as the cases of their use and application are respectively contained in the acts on the functioning of these services and entities.

Due to the fact that the circle of people authorised to use and apply direct coercive measures is wide, it is necessary to present the catalogue and scope of application of certain concepts and principles in relation to the rights of Prison Service officers.

The catalogue ${ }^{10}$ of direct coercive measures at the disposal of the Prison Service is as follows:

physical force in the form of the following techniques:

- transport;

- defence;

- attack;

- incapacitation;

handcuffs:

- worn on hands;

- worn on legs;

- combined;

incapacitating belt;

safety helmet;

3 Pepłowski J. (1989), Środki przymusu bezpośredniego [Direct coercion measures], Legionowo, p. 6.

4 Art. 1 of the Act of 9 April 2010 on the Prison Service, o Journal of Laws of 2020, item848.

5 Zoń M., Zadania Służby Więziennej [Duties of the Prison Service] (2013), in: Mazuryk M., Zoń M. (ed.) Służba Więzienna - komentarz [Prison Service - commentary], Wolters Kluwer SA, Warsaw, p. 29.

6 Art. 2 of the Act of 9 April 2010 on the Prison Service, Journal of Laws of 2020, item 848.

7 Journal of Laws of 2019, item 2418.

8 Ibid.

9 Ibid., Art. 2.

10 Art. 19 of the Act of 9 April 2010 on the Prison Service, Journal of Laws of 2020, item 848, in accordance with Art. 12 Paragraph 1 of the Act of 24 May 2013 on direct coercive measures and firearms, Journal of Laws of 2019, item 2418. 
service baton;

aqueous incapacitating agents;

police dog;

non-penetrating bullets;

$>$ chemical incapacitating agents in the form of:

- handheld incapacitating substance throwers;

- tear gas grenades;

- other devices intended for throwing incapacitating agents;

items intended for incapacitating persons by means of electrical energy;

security cell.

An example of a direct coercion measure, which is only at the disposal of officers of the Prison Service, among the services and entities specified in the Act on direct coercive measures and firearms, is a security cell.

\section{Preventive and interventional use of direct coercive measures in the Prison Service}

Under the Act on direct coercive measures and firearms, there is a distinction between the following concepts: the use and application of direct coercive measures. The legislator clarified this issue and included a definition of these terms in the dictionary.

The use of direct coercive measures is the application of a measure against a person. ${ }^{11}$ When explaining the concept of use, actual (physical) use should be presumed, i.e. the use of a given coercive measure by a person, e.g. an intervening officer, against another person (human being). ${ }^{12}$

On the other hand, the application is the implementation of a direct coercive measure against an animal or implementation of it with the aim to stop, block or immobilise a vehicle or to overcome an obstacle..$^{13}$ Thus, the use of direct coercive measures will always be an action against a person, while their application will be against an animal or a thing.

Officers of the Prison Service may use direct coercive measures in two ways, i.e. in an interventional (doctrinal concept) or preventive way.

The concept of interventional use does not function directly in the Act on direct coercive measures and firearms; however, it is used by the author to define the use of a direct coercive measure in the cases of Art. $11^{14}$ and Art. 35, Paragraph 2, point $10^{15}$ of the Act on direct coercive measures and firearms.

The differences between preventive and interventional uses include not only quantitatively different catalogues of direct coercive measures, various premises for the possibility of their use as well as distinct principles, e.g. with

11 Art. 4, point 6 of the Act of 24 May 2013 on direct coercive measures and firearms, Journal of Laws of 2019, item 2418.

12 Łabuz P., Malinowska I., Michalski M. (2020), Ustawa o środkach przymusu bezpośredniego i broni palnej [The act on direct coercive measures and firearms], p.14.

13 Art. 4, point 9 of the Act of 24 May 2013 on direct coercive measures and firearms, Journal of Laws of 2019, item 2418.

14 enforcing the behaviour required by law in accordance with the order issued by an entitled person; repelling a direct, unlawful attempt on the life, health or freedom of an entitled person or another person; preventing activities aimed directly at taking a life, affecting health or freedom of an entitled person or another person; preventing violation of public order or safety; preventing direct attacks on areas, objects or devices protected by an entitled person; protecting order or security in areas or facilities protected by an entitled person; preventing property damage; ensuring safety of a convoy or escort; arresting a person, preventing an escape or pursuit of that person; overcoming passive resistance; overcoming active resistance; preventing activities aimed at auto aggressive behaviour.

15 attempting a direct, unlawful attack on the life or health of an entitled person or another person, attempting escape by a person deprived of liberty, as well as in the pursuit of them or a person who carried out a direct unlawful attack on the premises of a penitentiary facility, detention centre or another organisational unit, in which the Prison Service ensures order and security. 
regards to documenting. ${ }^{16}$ The difference predominantly lies in the fact of use, since in the case of preventive use, the direct risk of the occurrence of the indicated effects ${ }^{17}$ does not have to exist, while in the case of emergency use it is an "ad hoc" action. Interventional use is applied following the occurrence of legally defined premises, as a reaction to an illegal action in order to prevent the current threat and immediately enforce obedience. ${ }^{18}$

By combining these two methods of use, it should be stated that the preventive use of direct coercive measures should take place in a situation where the conditions for emergency use have not yet been met, and the information obtained about a person or their behaviour justifies the need to take preventive measures. ${ }^{19}$

\section{The essence of the preventive use of direct coercive measures in the Prison Service}

The essence of the preventive use of direct coercive measures in the Prison Service is that a person deprived of liberty follows the officers' orders; however, due to the real possibility of occurrence of unlawful behaviours, such as escape, aggression towards other people or self-aggression, an authorised officer may use these measures. It should be emphasised that the use of direct coercion measures as preventive measures is optional and not obligatory.

In dictionary terms, prevention is avoidance, a precautionary measure, which prevents the occurrence of a phenomenon considered undesirable. ${ }^{20}$

On the other hand, "preventive use" should be understood as protective actions to prevent "something", i.e. anticipated effects or consequences of other actions, events or behaviours. ${ }^{21}$ The definition contained in the commentary to $\mathrm{Act}^{22}$ specifies this concept as a situation, in which the aim of this application is to prevent the possible violation of the law by a person against whom a given measure of direct coercion is applied.

Preventive use of direct coercive measures in the Prison Service is everyday life. The specific nature of the service necessitates frequent escorting ${ }^{23}$ and convoys ${ }^{24}$ of people deprived of liberty under increased security procedures, which include the undisputed preventive use of direct coercive measures.

The Prison Service has had practice in this area for many years. Referring to the Regulation of the Minister ${ }^{25}$ of Justice of 16 June 1971, it can be stated that already in those years, officers of the Prison Service had the power to use direct coercive measures for this purpose. The competences concerned only escorting, during which it was possible to use shackles as a precautionary measure to prevent escaping of an escorted person or symptoms of aggressiveness. ${ }^{26}$

16 Art. 52 of the Act of 24 May 2013 on direct coercive measures and firearms, Journal of Laws of 2019, item 2418, the entitled person referred to in Art. 2, Paragraph 1, point 11 of the Act (an officer of the Prison Service) does not document preventive use or application of direct coercive measures, unless it resulted in an injury to a person or the occurrence of other visible symptoms of a threat to the life or health of that person, their death or property damage.

17 Czebotar Ł., Gądzik Z., Łyżwa A., Michałek A., Świerczewska-Gąsiorowska A., Tokarski M. (2015), Ustawa o Policji [The Police Act]. Commentary. Published: LEX 2015, p. 6. (accessed: 21 July 2020).

18 Kubanek A., Ograniczenia... [Limitations...], op. cit., pp. 23-24.

19 Szwarc K. (2015), Stosowanie ustawy o środkach przymusu bezpośredniego i broni palnej z perspektywy doświadczeń Rzecznika Praw Obywatelskich [Application of the Act on direct coercive measures and firearms from the perspective of the Ombudsman's experience], [in:] Użycie broni palnej jako środka przymusu bezpośredniego [The use of firearms as a direct coercive measure], ed. R. Netczuk, University of Silesia in Katowice, p. 97.

20 Kopaliński W. (1999), Dictionary of foreign terms and phrases with almanac, Muza SA, Warsaw, p. 405.

21 Dubisz S. (ed.) (2003), The universal dictionary of the polish language, vol. III, Polish Scientific Publishers PWN, p. 353.

22 Łabuz P., Malinowska I., Michalski M (2020), The Act ..., op. cit., p. 66.

23 Escorting - moving a person deprived of liberty within the premises of a penitentiary facility or detention centre.

24 Convoy - moving a person deprived of liberty outside the premises of a penitentiary facility or detention centre.

25 The Regulation of the Minister of Justice of 16 June 1971 on the admissibility of the use of firearms by Prison Service officers as well as use of physical force and special security measures (Journal of Laws of 1971, No. 18, item 182).

26 Ibid., $\$ 11$. 
The change in the rules of the Prison Service in this matter took place on 1 September 1996, on the day of entry into force of the Act on the Prison Service of 26 April 1996. ${ }^{27}$ It consisted in the possibility of using a disabling belt and guides in addition to shackles as preventive measures during protective activities. ${ }^{28},{ }^{29}$ Moreover, this was permitted not only during convoy, but also during escorting people deprived of their liberty within the premises of penitentiary facilities and pre-trial detention centres.

Another modification was introduced in Article 19, section 6 of the Act of 9 April 2010 on the Prison Service. ${ }^{30}$ On the basis of this modification, officers of the Prison Service were equipped with powers of preventive use of the above measures in order to prevent the escape of a person deprived of liberty or symptoms of active aggression or self-harm. They had a protective helmet, handcuffs, a restraining belt, guides and technical devices blocking the knee joint at their disposal.

As presented above, the issue of the preventive use of direct coercive measures in the Prison Service has undergone significant modifications. The changes concerned not only the name of the right, but also the types of direct coercive measures and the purposes of their use.

Considering the current legal situation, the purpose of the rights given to officers of the Prison Service in the field of preventive use of direct coercive measures is: ${ }^{31}$

preventing the escape of a person deprived of liberty.

This primarily concerns situations during the escort of ${ }^{32}$ people deprived of their liberty and prevention of their escape, i.e. a crime of self-liberation ${ }^{33}$.

Another example of the possibility of using such measures for this purpose is bringing an inmate onto premises of a pre-trial detention centre or a penitentiary facility, where the technical and protective security in the form of an outer line of a protective fence is being renovated. ${ }^{34}$ The occurrence of an escape in this situation is also possible; however, this time from the premises of an organisational unit of the Prison Service.

According to commentary regarding the Act on direct coercive measures and firearms, the goal of a de facto detained person is to escape. ${ }^{35}$ On the other hand, the task of the Prison Service officers is to not let it happen, and in the event of an escape, they are obliged to pursue the fugitive. ${ }^{36}$

Thanks to appropriate procedures and professional performance of tasks by officers, the number of escapes of prisoners from convoys carried out by the officers of the Prison Service remains at a very low level.

\footnotetext{
27 Journal of Laws of 1996, No. 61, item 283.

28 Adamczak W., Jędrzejak K., Kuźma Z. (1998), Stosowanie środków przymusu bezpośredniego przez funkcjonariuszy Służby Więziennej [The use of direct coercive measures by officers of the Prison Service], Central Training Center of the Prison Service in Kalisz, p. 14.

29 Art. 19, Paragraph 5 of the Act of 26 April 1996 on the Prison Service, Journal of Laws of 1996, No. 61, item 283.

30 Journal of Laws of 2010, No. 239, item 523.

31 Art.13, Paragraph 1 of the Act of 24 May 2013 on direct coercive measures and firearms, Journal of Laws of 2019 , item 2418.

32 Ibid., Art. 4 point 3.

33 Art. $242 \S 1$ of the Act of 6 June 1997, Penal Code, Journal of Laws of 2020, item 1444, 1517.

$34 \S 31.1$ of the Regulation of the Minister of Justice of 17 October 2016 on ways of protection of organisational units of the Prison Service (Journal of Laws of 2016, item 1804).

35 Karpiuk M. (ed.) (2019) Ustawa o środkach przymusu bezpośredniego i broni palnej [The Act on direct coercive measures and firearms]. Commentary, Faculty of Law and Administration. University of Warmia and Mazury in Olsztyn, p.94.

$36 \S 65$ of the Regulation of the Minister of Justice of 17 October 2016 on ways of protection of organisational units of the Prison Service (Journal of Laws of 2016, item 1804).
} 
Table 1. List of escapes from Prison Service convoys in 2017-2020.

\begin{tabular}{|l|c|c|c|c|}
\hline \multirow{2}{*}{ SPECIFICATION } & \multicolumn{4}{|c|}{ Number of incidents } \\
\cline { 2 - 5 } & 2017 & 2018 & 2019 & 2020 \\
\hline Escape from a Prison Service convoy & 0 & 1 & 2 & 1 \\
\hline
\end{tabular}

Source: Biuro Ochrony i Spraw Obronnych CZSW

[Office of Security and Defence Affairs, Central Board of Prison Service], 2021.

In the author's opinion, if there are no statutory prohibitions ${ }^{37}$ on the use of a measure of direct coercion against a person deprived of liberty, in order to prevent escape, the individual should move during the escort by Prison Service officers at least in handcuffs placed on hands held at the front of the body. This primarily applies to inmates qualified to serve a sentence of imprisonment in a closed prison, people who are temporarily arrested as well as everyday situations, in which Prison Service officers move with the inmates on the premises of civilian health care facilities in order to provide health services. Another example of the use of direct coercive measures during convoys may be participation in a funeral of a family member of an inmate. ${ }^{38}$

The preventive use of direct coercive measures during convoys may also apply to inmates qualified to imprisonment in semi-open and open prisons. In the history of the Polish prison system, there have been instances where convicts from semi-open type prisons escaped from convoys carried out by officers of the Prison Service. This right is applied less frequently in relation to these categories of inmates because they have a wider range of possibilities to leave a penitentiary facility.

The negative effect of not using the powers of preventive use of these measures is the disciplinary and even criminal liability of Prison Service officers in a situation where an inmate escapes.

preventing symptoms of aggression.

The persistently high number of assaults on officers and common inmate aggression mean that officers are obliged to take all actions within the scope of their powers to prevent the occurrence of this type of behaviour.

Table 2. List of assaults in 2017-2020.

\begin{tabular}{|l|c|c|c|}
\hline \multirow{2}{*}{ SPECIFICATION } & \multicolumn{3}{|c|}{ Number of incidents } \\
\cline { 2 - 4 } & 2017 & 2018 & 2019 \\
\hline Assault on an officer on duty & 112 & 148 & 139 \\
\hline
\end{tabular}

Source: Biuro Ochrony i Spraw Obronnych CZSW

[Office of Security and Defence Affairs, Central Board of Prison Service], 2021.

The most common (but not the only) situation of preventive use of the above measures by Prison Service officers is the performance of official duties in direct contact with dangerous inmates, ${ }^{39}$ who have been classified in this category in connection with an active attack on a public official or another person employed at a penitentiary facility or detention centre. ${ }^{40}$ Another example of using a direct coercive measure for this purpose may be bringing an inmate to a prison director to inform them about the imposition of a disciplinary penalty in the event that they verbally declared aggressive attitude.

prevention of auto aggressive behaviour.

37 Art. 9, Paragraph 1 of the Act of 24 May 2013 on direct coercive measures and firearms, Journal of Laws of 2019, item 2418, i.e. a visibly pregnant woman, people with a visible disability.

38 Art. 141a of the Act of 6 June 1997, Executive Penal Code, Journal of Laws of 2021, item 53.

$39 \S 2$, point 18 of the Regulation of the Minister of Justice of 17 October 2016 on ways of protection of organisational units of the Prison Service, Journal of Laws of 2016, item 1804 - an inmate classified as posing a serious threat to the public or a serious threat to the safety of the penitentiary facility.

40 Art. 88a §1, point 2b of the Act of 6 June 1997, Executive Penal Code, Journal of Laws of 2021, item 53. 
The above purpose of preventive use of direct coercive measures is related to the obligation towards people deprived of their liberty, which is imposed on the Prison Service. It consists in taking appropriate measures to ensure the personal safety of convicts during their sentence. ${ }^{41}$

Preventive use of coercive measures by officers of the Prison Service may also apply to people other than those deprived of liberty. This results from Article 13, Paragraph 1 of the Act on direct coercive measures and firearms, which also refers to detained persons. Chapter 3 of the Act on the Prison Service lists the powers of Prison Service officers. One of the powers, which directly result from Article 18, is the possibility of detention on the premises of an organisational unit for the purpose of immediate transfer of people, for whom there is a reasonable suspicion of committing a prohibited act under penalty of law, to the Police. ${ }^{42}$

\section{Rules for the use of direct coercive measures, which can be used as a preventive measure}

In the current legal circumstances ${ }^{43}$ the Prison Service has the following range of direct coercive measures, which can be used as preventive measures, at its disposal:

physical force in the form of transport techniques.

Physical force indicates direct impact on the muscles of a person against whom it is applied. ${ }^{44}$ Each trained officer of the Prison Service is equipped with this measure.

Transport techniques belong to the mildest direct coercive measures in the form of physical force. They were introduced into the preventive catalogue of the Polish Prison Service in 2013 and are used to move (transfer) a person to a desired place or direction. Depending on the level of resistance exerted by the person being transported, grips can be used to restrict or block the freedom of movement using levers on the limb joints. ${ }^{45}$

These measures can involve grabbing the inmate by the arm or applying a shoulder-joint lever when escorting or leading them to the indicated place.

handcuffs - all types, ${ }^{46}$ i.e. those worn over the hands, those worn over the legs and combined handcuffs. ${ }^{47}$

Handcuffs are the most frequently used preventive direct coercive measure by the Prison Service officers. Their purpose is to partially immobilise the limbs. ${ }^{48}$ They should be put on in such a way as not to cause abrasion of the epidermis of the inmate's or other person's limbs. Moreover, they should not be excessively tightened so as not to stop blood circulation.

restraining belt; 49

There are two types of restraining belts in the Prison Service. These include:

- one-piece belt,

- multi-piece belt.

41 Ibid., Art. 108.

42 Art. 18, Paragraph 1, point 5 of the Act of 9 April 2010 on the Prison Service, Journal of Laws of 2020, item 848.

43 Art. 13, Paragraph 1 of the Act of 24 May 2013 on direct coercive measures and firearms, Journal of Laws of 2019, item 2418 in accordance with Art. 19 of the Act of 9 April 2010 on the Prison Service, Journal of Laws of 2020, item 848.

44 Kubanek A. (2019), Ograniczenia ... [Limitations...], op. cit., p. 47.

45 Gospodarowicz Z., Zając Z. (2013), Uprawnienia funkcjonariuszy Służby Więziennej w zakresie użycia lub wykorzystania środków przymusu bezpośredniego i broni palnej [Authority of Prison Service officers to use or apply direct coercive measures and firearms], Office of Security and Defence Affairs, Central Board of the Prison Service in Warsaw, p. 7.

46 Opinion of 10 May 2013 on the Act on direct coercive measures and firearms, p.7.

47 Art. 12, Paragraph 1, point 2 of the Act of 24 May 2013 on direct coercive measures and firearms, Journal of Laws of 2019, item 2418.

48 Ibid., Art. 15, Paragraph 3.

49 Ibid., Art. 12, Paragraph 1, point 4. 
Considering the current equipment of the Prison Service with restraining belts, only a one-piece restraining belt may be used as a preventive measure. The multi-piece belt, which the Prison Service is also equipped with, is not applied as a preventive measure because it is only used with a bed of an appropriate structure. During the use of a multi-piece belt, the bed is in a safety cell - a soundproof room.

At present, the Prison Service uses one type of one-piece restraining belt. It is a so-called classic one-piece incapacitating belt, which is characterised by two rings attached to a leather belt.

The main purpose of using this measure is to restrain the hands. ${ }^{50}$ Moreover, the basic principles of using it include:

- its application if the use of other direct coercive measures is not possible or may turn out to be ineffective. ${ }^{51}$

No explanation of the above principle is provided in the legislation. According to the author, this may refer to a situation where:

$\checkmark$ a direct coercive measure in the form of handcuffs cannot be used due to the unnatural limb construction of the person (e.g. thick wrists) or their muscular body structure (i.e. it is not possible to put handcuffs on hands placed behind one's back);

$\checkmark$ the person breaks the handcuffs after putting them on or moves their hands, which were handcuffed behind their back, to the front and takes off the protective helmet or attacks the officers;

$\checkmark$ its use cannot cause any breathing difficulties or stop blood circulation. ${ }^{52}$

Similarly to the case of combined handcuffs and handcuffs for the legs and hands, the legislation does not specify the method of putting a one-piece restraint belt on. Considering its design, it should be worn at a hip level, and its rings should not stop the blood circulation. The rings can be worn on hands held at the back or at the front of the body.

protective helmet.

Apart from prevention itself, this is another issue concerning the use of direct coercive measures, in which the Prison Service has the greatest experience among all Polish services.

A protective helmet is a direct coercive measure, which is used to prevent self-injury of the head..$^{53}$

The basic principles of using this measure include the application of handcuffs behind the back or employing a one-piece restraining belt ${ }^{54}$ to prevent the removal of the protective helmet.

Photographs 3 and 4 . The use of handcuffs on hands held at the front of the body and a restraining belt with a protective helmet.

It should be noted that as prevention measures, direct coercive measures may be used against any person, with the exception of visibly pregnant women, people whose appearance indicates young age (up to 13 years old) and those with visible disabilities. ${ }^{55}$ This results from the principle, which states that in relation to these categories of people, officers may only use physical force in the form of techniques of incapacitation.

\footnotetext{
50 Ibid., Art. 16, Paragraph 2.

51 Ibid., Art. 16, Paragraph 1.

52 Ibid., Art. 16, Paragraph 4.

53 Ibid., Art. 17, Paragraph 2.

54 Ibid.

55 Ibid., Art. 9, Paragraph 1.
} 


\section{Conclusions}

The preventive use of direct coercive measures is an indispensable tool for the implementation of statutory tasks of the Polish Prison Service in the area of security, in particular to ensure order and security in penitentiary facilities and detention centres as well as to protect the public against perpetrators of crimes or fiscal offences incarcerated in penitentiary facilities $a^{5} d^{56}$ detention centres.

Among its purposes, prevention of the escape of a person deprived of liberty is the most common reason for the use of this measure by the Polish Prison Service officers. This goal is closely related to the task of protecting the public against perpetrators of crimes and fiscal offences incarcerated in penitentiary facilities and detention centres. It is commonly believed that a prisoner, who escaped from a penitentiary facility (or a convoy) and is in hiding, is in a particularly criminogenic situation. They may commit a crime in order to obtain means of subsistence, food, clothing or documents. They may also commit a crime against a person to prevent them from notifying law enforcement authorities about their location. ${ }^{57}$ Hence, it is necessary to counteract such events, e.g. by using handcuffs during convoy. This rule results from good prison practice and the principle that prevention is better than eradication.

It should be emphasised that in the event of an escape, officers of the Prison Service are entitled by law to the use of direct coercive measures in an intervention manner. This includes the use of a firearm in relation to ${ }^{58} \mathrm{a}$ fugitive, which consists in taking a shot at a person utilising penetrating ammunition. ${ }^{59}$ This may result in injury, and in extreme cases, even loss of life of a prisoner or bystander.

It is noteworthy that as a general rule, during the convoy of people deprived of liberty, officers of the Prison Service are armed. This applies to convoys of all categories of inmates. The only exception to this principle is escorting an inmate qualified to serve a sentence in a semi-open or open prison by an unarmed officer. ${ }^{60}$

The second most frequent purpose of the use of preventive direct coercive measures by Prison Service officers is to prevent aggressive behaviours among prisoners. This particularly concerns ensuring order and security in penitentiary facilities and detention centres. The use of these procedures is predominantly aimed at minimising the risk of undesirable events consisting in attempts to take the life or affect the health of a prison officer or employee, inmate or other person who have direct contact with aggressive inmates.

The preventive use of direct coercive measures is undoubtedly the lightest form of using such measures as a tool for the implementation of statutory tasks by the Prison Service in Poland. The undertaken actions must be adequate to the risk and implemented in accordance with applicable law and the principle of humane treatment of persons deprived of liberty. ${ }^{61}$ Such actions should take place in a way that causes the least possible harm to the person against whom they are applied. Moreover, its use should be abstained when the goal has been achieved. ${ }^{62}$

\section{References}

Adamczak W., Jędrzejak K., Kuźma Z. (1998), Stosowanie środków przymusu bezpośredniego przez funkcjonariuszy Służby Więziennej [The use of direct coercive measures by officers of the Prison Service], Central Training Centre of the Prison Service in Kalisz.

Czebotar Ł., Gądzik Z., Łyżwa A., Michałek A., Świerczewska-Gąsiorowska A., Tokarski M. (2015), The Police Act. Commentary. Published: LEX 2015, p. 6. (accessed: 21 July 2020).

56 Art. 2 of the Act of 9 April 2010 on the Prison Service, Journal of Laws of 2020, item 848.

57 Michelis J. de (1997), Ucieczki osób pozbawionych wolności [Escapes of people deprived of liberty], (in:) Stan i węzłowe problemy polskiego więziennictwa [The condition and key problems of the Polish Prison System]. Part II, RPO Bulletin, Warsaw, p. 221.

58 Art. 45, point 5 of the Act of 24 May 2013 on direct coercive measures and firearms, Journal of Laws of 2019, item 2418.

59 Ibid., Art. 4 point 7.

$60 \$ 84.5$ of the Regulation of the Minister of Justice of 17 October 2016 on ways of protection of organisational units of the Prison Service (Journal of Laws of 2016, item 1804).

61 Art. 2, point 4 of the Act of 9 April 2010 on the Prison Service, Journal of Laws of 2020, item 848.

62 Art. 7 of the Act of 24 May 2013 on direct coercive measures and firearms, Journal of Laws of 2019, item 2418. 
Dubisz S. (ed.) (2003), The universal dictionary of the polish language, vol. III, Polish Scientific Publishers PWN.

Dyduch L., Maciejczyk R. (2012), Wybrane formy organizacyjne działań podmiotów uprawnionych w zakresie bezpieczeństwa wewnętrznego państwa [Selected organisational forms of actions of authorised entities within the scope of internal security of the state]. Part I, Środki przymusu bezpośredniego i broń palna [Direct coercive measures and firearms], Warsaw.

Gospodarowicz Z., Zając Z. (2013), Uprawnienia funkcjonariuszy Służby Więziennej w zakresie użycia lub wykorzystania środków przymusu bezpośredniego i broni palnej [Powers of the Prison Service officers with regard to the use and application of direct coercive measures and firearms], Biuro Ochrony i Spraw Obronnych [Security and Defence Affairs Office]. The Central Board of Prison Service in Warsaw.

Karpiuk M. (ed.) (2019), Ustawa o środkach przymusu bezpośredniego i broni palnej [The Act on direct coercive measures and firearms]. Commentary, Olsztyn.

Kopaliński W. (1999), Dictionary of foreign terms and phrases with almanac, Muza SA.

Kubanek A. (2019), Ograniczenia praw jednostki praw jednostki przez zastosowanie środków przymusu bezpośredniego w celu zapewnienia bezpieczeństwa i porządku publicznego [Limitation of the rights of an individual by the use of direct coercive measures to ensure security and public order], Bydgoszcz.

Łabuz P., Malinowska I., Michalski M. (2020), Ustawa o środkach przymusu bezpośredniego i broni palnej [The act on direct coercive measures and firearms], Warsaw.

Malec J. (1997), Stan i węzłowe problemy polskiego więziennictwa [The condition and key problems of the Polish Prison System]. Part II, RPO Bulletin, Warsaw.

Mazuryk. M, Zoń M. (ed.) (2013), Prison Service - commentary, Warsaw.

Netczuk R. (red.) (2015), Użycie broni palnej jako środka przymusu bezpośredniego [The use of firearms as a direct coercion measure], University of Silesia in Katowice.

Pepłowski J. (1989), Środki przymusu bezpośredniego [Direct coercive measures], Legionowo.

\section{Legislative acts:}

- Opinion of 10 May 2013 on the Act on direct coercive measures and firearms.

- The Regulation of the Minister of Justice of 16 June 1971 on the admissibility of the use of firearms by the Prison Service officers as well as application of physical force and special security measures (Journal of Laws of 1971, No. 18, item 182.

- The Regulation of the Minister of Justice of 17 October 2016 on the methods of protecting organisational units of the Prison Service, Journal of Laws of 2016, item 1804.

- The Act of 26 April 1996 on the Prison Service, Journal of Laws of 1996, No. 61, item 283.

- The Act of 6 June 1997, Executive Penal Code, Journal of Laws of 2021, item 53.

- The Act of 6 June 1997, Penal Code, Journal of Laws of 2020, item 1444, 1517.

- The Act of 9 April 2010 on the Prison Service, Journal of Laws of 2010, no. 79, item 523.

- The Act of 9 April 2010 on the Prison Service, Journal of Laws of 2010, no. 79, item 848.

- The Act on direct coercive measures and firearms of 24 May 2013, Journal of Laws of 2019, item 2418.

Robert NOWACKI serves as a senior specialist at the Institute of Security Sciences at the Academy of Justice in Warsaw. He graduated from the Faculty of Pedagogy. He manages the Laboratory of Protection and Defence of Organizational Units of the Prison Service. It carries out classes in in subjects the issues of security and safety of penitentiary units. He specializes in the issues related to the use of direct coercive measures in the Prison Service, management of threats to the security of organizational units of the Prison Service and the implementation of protective procedures in prisons and pre-trial detention centres.

ORCID ID: https://orcid.org/0000-0002-1620-8493

Register for an ORCID ID:

https://orcid.org/register

This work is licensed under the Creative Commons Attribution International License (CC BY). http://creativecommons.org/licenses/by/4.0/ 